\title{
METASOMATIC PROCESSES IN SUBCONTINENTAL LITHOSPHERIC MANTLE BENEATH THE SIBERIAN PLATFORM.
}

L.V. Solovjeva; V.G. Barankevich and L.L. Lipskaya. Institute of the Earth's Crust, 664033 - Yakutsk, USSR. IRGIREDMET, Irkutsk.

Metasomatic alterations of substance of deep-seated xenoliths from the Udachnaya kimberlite pipe, based on textural and petrographic evidence may be attributed to two episodes of different age. A characteristic mineral association represented by phlogopite, Cr-rich spinel, sulfides and more rare graphite and apatite appears to belong to the earlier episode of metasomatism. Phlogopite forms relatively large plates $(0,5-5 \mathrm{~mm})$ which are homogenous within the limits of one grain and specimen except for very narrow rims (50$150 \mathrm{mkm}$ ) belonging to the later process. $\mathrm{TiO}_{2}$ and $\mathrm{Cr}_{2} \mathrm{O}_{3}$ in phlogopites from a part of specimens are $<1 \%$ and correspond to primary micas reported by Carswell (1975) and its contents in other specimens are higher. Graphite occurs in two websterite specimens containing large $(1-2 \mathrm{~cm})$ exsolved pyroxenes healed by fine grained granoblastic aggregate of phlogopite, garnet, pyroxenes, sulfides and graphite. Grains of graphite are a part of granoblastic fabric and exhibit intergrowths with garnet and phlogopite on grain margins. Isotopic composition of carbon in metasomatic graphite yield $\delta^{13} \mathrm{C}$ values equal to $-7,83$ and $-10,82^{\circ} / 00$ (Galimov et al., 1987). This carbon which is lighter than the carbon used for the mantle datum $\left(2-7^{\circ} / 00\right)$, is nevertheless of obvious mantle origin deriving from greater depths than those of websterite equilibrium ( $\sim 25 \mathrm{kbar}$ ).

The lighter isotopic composition of carbon may be explained by removal of heavy carbon during carbonatization of the mantle 
environment (Galimov et al., 1987), or by making the carbon lighter at expense of a successive graphite precipitation within rising reduced fluid $\left(\mathrm{CH}_{4}, \mathrm{H}\right)$. The latter mechanism is confirmed by $\mathrm{f}_{2}$. values corresponding to position between buffer curves MW-IW (for 01-Opx-Sp equilibrium). Temperatures estimates obtained from En-Di solvus indicate the decrease in following order: calculated homogenized pyroxenes in large relict crystals, calculated homogenized pyroxenes in matrix, compositions of pyroxenes without exsolved intergrowths in matrix. Apatite occurs in one specimen of orthopyroxenite where, together with small crystals of phlogopite, pyroxenes and sulfides, it heals large exsolved grains of orthopyroxene.

Textural evidences suggest that the early metasomatism developed prior to rock deformation. This process appears to take place at the Early Archean and is related to evacuation of reduced fluids and crust granitization.

The late metasomatic process is pervasive in xenoliths of various lithology and is manifested in reaction rims on minerals of primary paragenesis. This type of metasomatism is abundantly developed in deep-seated xenoliths of kimberlites and lamproites from many areas of the world. It occurs in the form of polymineral rims on garnet: Al-orthopyroxenes, Al-clinopyroxenes, chemically heterogeneous spinel, phlogopite, rare amphibole of pargasite type. Orthopyroxene is replaced by acicular amphibole, Al-clinopyroxene, spinel. Sulfides are totally or partially substituted by djerfisherite. This process is responsible for melting patches in xenoliths. $\mathrm{f}_{2}$ value calculated from ilmenite-spinel equilibrium in reaction rims of eclogite xenolith and melting patches into megacrust of Cr-low garnet is slighty below HM (hematite-magnetite) curve. Such a metasomatic type is characteristic of the prekimberlite episode and is probably related to oxidized asthenospheric fluids. 